2 Wei Liao ${ }^{1}$, Waisudin Badri ${ }^{1}$, Amani H Alhibshi ${ }^{2}$, Emilie Dumas ${ }^{1}$, Sami Ghnimi, ${ }^{1}$ Adem

3 Gharsallaoui ${ }^{1}$, Abdelhamid Errachid ${ }^{3}$, Abdelhamid Elaissari ${ }^{1,3}$

4

5

6

1) Univ Lyon, University Claude Bernard Lyon-1, CNRS, LAGEP-UMR 5007, F69622 Lyon, France

${ }^{2}$ Department of Neuroscience Research, Institute of Research and Medical Consultations (IRMC), Imam Abdulrahman Bin Faisal University, P.O Box 1982, Dammam 31441, Saudi Arabia.

${ }^{3}$ Univ Lyon, University Claude Bernard Lyon-1, CNRS, ISA- UMR 5280, CNRS, F-69100 Villeurbanne, France.

\title{
Abstract:
}

Nigella Sativa Oil (NSO), extracted from seeds of Nigella Sativa, are widely used in traditional medicine and foodstuff in around the world because they are rich in a variety of phytochemicals. Nigella sativa essential oil (NSEO) are regarded as a promising trend to get more functional benefits from NSO, which can be obtained by distillation methods. Thymoquinone, thymohydroquinone, $\rho$-cymene, carvacrol and $t$-anethole are the main components of NSEO. These active compounds, especially thymoquinone, showed antioxidants, antibacterial and anti-inflammatory activities with low toxicity, which have been considered a useful source of food application. NSEO are, nowadays, still used in food in limited forms due to their low water solubility, high volatility and strong organoleptic properties; However, encapsulation technology could tackle these challenges. Thus, the ambition of this chapter is to provide an overview of NSEO and their advantageous properties usage on food application. Furthermore, biological activities of NSEO and encapsulated NSEO in addition to its technological and potential utilization in food will be presented.

Keywords: Nigella Sativa; Nigella Sativa Essential oil; Thymoquinone; Food application; Encapsulation; 
1. Introduction

33 There has been an increasing interest in the use of unconventional oil seeds because

34 their ingredients have unique properties that may increase the supply of new products in food application. In recent years, people have paid more attention to food safety, and the demand for "natural" food additives has received increasing attention. The current research focus on plant essential oil as a natural source of antibacterial and antioxidant compounds. Nigella sativa is well known as black seed or black cumin, which belong to the botanical family of Ranunculaceae (Aggarwal and Kunnumakkara, 2009). It is an annual plant from Southwest Asia, North Africa, and Southern Europe. In addition,

41 Nigella sativa oil (NSO) has been used as a food additives or medicine improve appearance and taste of products, and to treat fever, headache, anxiety, diarrhea, asthma, and stroke throughout the history, owing to different complex chemical substances (Walton et al., 1999). Different pharmacological trials have been carried out to consider its constituents. NSO also contains a small amount of volatile oil (NSEO), which has functional properties due to its active compounds: thymoquinone, thymohydroquinone, thymol, carvacrol and p-cymene (Fig.1) (Mariod et al., 2009; Kanter, 2008). Due to these compounds, recently, many biological properties of Nigella sativa seeds and its oils have been investigated, such as antibacterial (Ferdous et al., 1992), antioxidant

50 (Mariod et al., 2009), antitumor (Worthen et al., 1998), hyperglycemia and 51 hypercholesterolemia (Sultan et al., 2009). In addition, NSEO are regarded as a 52 promising trend to get more functional benefits from Nigella sativa, which can be obtained by vapor or hydro distillation methods. However, the use of NSEO in food application still have some limitations due to their low efficacy as food additives mixing with other medias, their low solubility and their instability. Effective encapsulation systems are considered to tackle these challenges in a certain degree. Thus, the purpose of this chapter is to present and discuss the chemical composition, and biological properties of NSEO, in order to explore their valuable uses for the development of food industry. 
<smiles>CC1=CC(=O)C(C(C)C)=CC1=O</smiles>

Thymoquinone<smiles>Cc1cc(O)c(C(C)C)cc1O</smiles>

Thymohydroquinone<smiles>Cc1ccc(C(C)C)c(O)c1</smiles>

Thymol<smiles></smiles>

Nigellicine<smiles>Cc1ccc(C(C)C)cc1</smiles>

p-Cymene<smiles>CC1=CCC2(C(C)C)CC1C2</smiles>

$\alpha$-Thujene

Fig. 1. Chemical structure of active ingredient of Nigella sativa essential oil.

\section{Description and chemical composition of Nigella sativa essential oil}

Nigella sativa seeds are reported with a rich source of many important nutrients, which contain protein, polylactide, $30-44.2 \%$ fixed oil, $0.4-1.49 \%$ essential oil, sterol, alkaloid, crude fiber, and minerals (Khan and Ather, 2006). Linoleic acid, oleic acid, palmitic acid were the main fatty acids in fixed oil. Phytochemical research of the NSEO had revealed the identification of bioactive compounds representing around $85 \%$ of the total amount (Mohamed F. Ramadan, 2016). Gas chromatography-mass spectrometer revealed the new ones: thymoquinone $(42.4 \%), p$-cymene (14.1\%), carvacrol $(10.3 \%)$, longifolene (6.1\%) and 4-terpineol (5.1\%) (Hossein Mahmoudvand et al., 2014b) as indicated in Table 1. A higher content of $p$-cymene $(49.48 \%)$ and lower content of thymoquinone $(0.79 \%)$ was found at Tunisian NSEO by GC-EIMS (Jrah Harzallah et al., 2011). High levels of $p$-cymene in NSEO may help to increase its commercial value, because this monosaccharide is important in the industry as intermediate for synthetic fragrance, drug and herbicides (Martín-Luengo et al., 2008). Very low content of thymoquinone was found in Nigella sativa seeds grown in Iran. Among them, the major compounds of NSEO were trans-anethole (38.3\%), p-cymene (14.8\%), limonene (4.3\%), and carvone (4.0\%) (Nickavar et al., 2003). Similar findings were found by 
81 D'Antuono (D'Antuono et al., 2002) and they presented NSEO had higher variability of

82 essential oil composition in relation to different sowing date. Above all, it can be

83 inferred that the active content of NSEO from different sources is significantly different,

84 which may be attributed to the environmental conditions, the time of sowing and the

85 conditions of seed storage.

86

87

Table 1. Proximate composition of different source of Nigella sativa essential oil

\begin{tabular}{|c|c|c|c|c|c|c|c|c|c|}
\hline \multirow{2}{*}{$\mathrm{N}$} & \multicolumn{8}{|c|}{ Content of Compound } & \multirow[b]{2}{*}{ Reference } \\
\hline & Thymoquinone & $\begin{array}{l}p \text { - } \\
\text { cymene }\end{array}$ & Carvacrol & Longifolene & $\begin{array}{l}\text { Terpinen- } \\
\text { 4-ol }\end{array}$ & $\begin{array}{l}\alpha- \\
\text { Thujene }\end{array}$ & Limonene & $\begin{array}{l}\alpha- \\
\text { Pinene }\end{array}$ & \\
\hline 1 & 4.47 & 56.67 & 1.68 & 0.79 & 0.31 & 16.35 & 2.41 & 3.58 & (Badri et al., 2018) \\
\hline 2 & 0.79 & 49.48 & 0.55 & 0.30 & 0.38 & 18.93 & 2.89 & 5.44 & $\begin{array}{l}\text { (Jrah Harzallah et } \\
\text { al., 2011) }\end{array}$ \\
\hline 3 & 11.27 & 36.20 & 2.12 & 6.32 & 2.37 & 10.03 & 1.76 & - & $\begin{array}{l}\text { (Mohamed F. } \\
\text { Ramadan, 2016) }\end{array}$ \\
\hline 4 & 0.6 & 14.8 & 1.6 & 0.7 & 0.7 & 2.4 & 4.3 & 1.2 & $\begin{array}{l}\text { (Nickavar et al. } \\
\underline{2003)} \\
(\underline{\text { Hossein }}\end{array}$ \\
\hline 5 & 42.4 & 14.10 & 0.08 & 6.10 & 5.10 & 1.50 & 1.70 & 0.04 & $\begin{array}{l}\text { Mahmoudvand et } \\
\text { al., 2014b) }\end{array}$ \\
\hline 6 & 3.0 & 60.5 & 2.4 & 0.9 & 2.1 & 6.9 & 1.4 & 1.7 & $\begin{array}{l}\text { (Bourgou et al., } \\
2010)\end{array}$ \\
\hline 7 & 52.6 & 25.8 & - & 1.5 & - & 10.5 & 1.1 & 2.8 & $\begin{array}{l}\text { (Shaaban et al., } \\
\text { 2015) }\end{array}$ \\
\hline
\end{tabular}

88

89 3. Food application of Nigella Sativa essential oil

90 To the best of our knowledge, some of recent studies employed essential oils in food

91 products were collected as Table 1. Applied essential oils mechanism of action, target

92 microorganisms and role are described.

93

94

Table 2. Essential oil applications in foods

\begin{tabular}{|c|c|c|c|c|}
\hline Essential oil & Properties & Food application & Pathogens & Reference \\
\hline
\end{tabular}




\begin{tabular}{|c|c|c|c|c|}
\hline \multirow{7}{*}{ Oregano } & \multirow{6}{*}{$\begin{array}{l}\text { Antibacteria } \\
1 \text { activity, } \\
\text { food } \\
\text { preservative }\end{array}$} & $\begin{array}{l}\text { Inhibitory antimicrobial effect } \\
\text { on ready to eat vegetables } \\
\text { (carrot } \& \text { lettuce) }\end{array}$ & $\begin{array}{l}\text { Bacillus cereus, E. coli, Listeria } \\
\text { spp., Staphylococcus aureus, } \\
\text { Lactobacillus spp., } \\
\text { Pseudomonas spp., } \\
\text { Enterobacter spp., Salmonella }\end{array}$ & $\frac{\text { (Gutierrez et al., }}{\underline{2008} \text { ) }}$ \\
\hline & & $\begin{array}{l}\text { Inactivated bacteria in iceberg } \\
\text { lettuce }\end{array}$ & Salmonella typhimurium & $\frac{\text { (Gündüz et al., }}{\underline{2010)}}$ \\
\hline & & $\begin{array}{l}\text { Antibacterial activity in fresh } \\
\text { ground beef patties }\end{array}$ & $\begin{array}{l}\text { E. coli, Staphylococcus- } \\
\text { aureus, Pseudomonasaeruginos } \\
\text { a, Lactobacillus plantarum }\end{array}$ & $\frac{(\text { Emiroğlu et al., }}{\underline{2010} \text { ) }}$ \\
\hline & & $\begin{array}{l}\text { Antimicrobial activity in stored } \\
\text { minced sheep meat }\end{array}$ & S. enteritidis & $\frac{\text { (A Govaris et al., }}{\underline{2010} \text { ) }}$ \\
\hline & & $\begin{array}{l}\text { Reduced microbial populations } \\
\& \text { extended shelf-life of fresh } \\
\text { chicken meat \& liver }\end{array}$ & $\begin{array}{l}\text { Yeasts, Lactic acid } \\
\text { bacteria,Enterobacteriaceae, } \\
\text { Brochothrix- } \\
\text { thermosphacta, Pseudomonas } \\
\text { spp. }\end{array}$ & $\begin{array}{l}\text { (Chouliara et al., } \\
\underline{\text { 2007; Hasapidou }} \\
\frac{\text { and Savvaidis, }}{\underline{2011} \text { ) }}\end{array}$ \\
\hline & & $\begin{array}{l}\text { Reduced survival rate of } \\
\text { bacteria in Feta cheese }\end{array}$ & E. coli,L. monocytogenes & 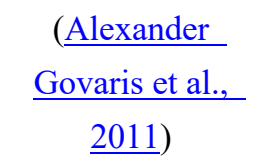 \\
\hline & Antifungal & $\begin{array}{l}\text { Reduced fungal infections in } \\
\text { tomatoes, } \\
\text { \&cucumbers }\end{array}$ & $\begin{array}{l}\text { Botrytis cinerea, Penicillium } \\
\text { italicum, P. digitatum }\end{array}$ & $\frac{\text { (Vitoratos et al., }}{\underline{2013} \text { ) }}$ \\
\hline \multirow{4}{*}{ Rosemary } & \multirow{2}{*}{$\begin{array}{l}\text { Antibacteria } \\
1\end{array}$} & $\begin{array}{l}\text { Inhibited bacteria in fresh leafy } \\
\text { vegetables }\end{array}$ & $\begin{array}{l}\text { E. coli, L. monocytogenes, } S \text {. } \\
\text { enteritidis }\end{array}$ & $\frac{\frac{(\text { de Medeiros }}{\text { Barbosa et al., }}}{\underline{2016)}}$ \\
\hline & & $\begin{array}{l}\text { Reduced bacterial growth \& } \\
\text { extended shelf-life in meat } \\
\text { products }\end{array}$ & Lactic acid bacteria & $\frac{\text { (Badia et al., }}{\underline{2019} \text { ) }}$ \\
\hline & Antifungal & $\begin{array}{l}\text { Controlled fungal growth and } \\
\text { disease in passion fruit }\end{array}$ & $\begin{array}{l}\text { Alternaria spp., Fusarium spp., } \\
\text { Colletotrichum spp., } \\
\text { Penicillium spp. }\end{array}$ & $\frac{\text { (Waithaka et al., }}{\underline{\text { 2017) }}}$ \\
\hline & Antioxidant & $\begin{array}{l}\text { Extended shelf-life of cream } \\
\text { cheese } \& \& \text { decreased } \\
\text { fermentative deterioration }\end{array}$ & - & $\frac{\text { (Olmedo et al., }}{\underline{2013})}$ \\
\hline \multirow[b]{2}{*}{ Thyme } & \multirow{2}{*}{$\begin{array}{l}\text { Acaricides, } \\
\text { Antimicrobi } \\
\text { al, food } \\
\text { preservative }\end{array}$} & Toxic to red mite in poultry & Dermanyssus gallinae & $\frac{\text { (George et al., }}{\underline{2009)}}$ \\
\hline & & $\begin{array}{l}\text { Extended shelf-life \& reduced } \\
\text { microbial population of lamb } \\
\text { meat }\end{array}$ & Enterobacteriaceae & $\frac{\text { (Karabagias et }}{\underline{\text { al., 2011) }}}$ \\
\hline
\end{tabular}




\begin{tabular}{|c|c|c|c|c|}
\hline & \multirow[b]{2}{*}{$\begin{array}{l}\text { Fungicidal } \\
\text { effect }\end{array}$} & $\begin{array}{l}\text { Inhibited microorganism } \\
\text { \&extendedshelf-life of papayas }\end{array}$ & $\begin{array}{l}\text { Colletotrichum gloeosporioides, } \\
\text { Rhizopus stolonifer }\end{array}$ & $\frac{\text { (Bosquez-Molina }}{\underline{\text { et al., 2010) }}}$ \\
\hline & & $\begin{array}{l}\text { Inhibited the mycelium growth } \\
\& \quad \text { spore germination in } \\
\text { strawberry, tomato \& } \\
\text { cucumber }\end{array}$ & $\begin{array}{l}\text { Botrytis, Penicillium italicum, } \\
\text { P. digitatum }\end{array}$ & $\frac{\text { (Vitoratos et al., }}{\underline{2013})}$ \\
\hline \multirow[b]{2}{*}{ Lemongrass } & $\begin{array}{l}\text { Antimicrobi } \\
\text { al }\end{array}$ & $\begin{array}{l}\text { Inactivated microorganisms in } \\
\text { Apple, pear, \&melon juices }\end{array}$ & S. enteritidis, E. coli,L. innocua & \multirow{2}{*}{$\begin{array}{c}\frac{(\text { Raybaudi- }}{\underline{\text { Massilia et al., }}} \\
\frac{2006 ;}{\underline{\text { Paranagama et }}} \\
\underline{\text { al., 2003) }}\end{array}$} \\
\hline & $\begin{array}{l}\text { Antifungal, } \\
\text { antiaflatoxi } \\
\text { genic }\end{array}$ & $\begin{array}{l}\text { Inhibited aflatoxin formation } \& \\
\text { fungal growth in stored rice }\end{array}$ & Aspergillus flavus & \\
\hline Mint & $\begin{array}{l}\text { Antibacteria } \\
1\end{array}$ & $\begin{array}{l}\text { Inactivated bacteria in yogurt } \\
\text { sample }\end{array}$ & L. monocytogenes, L. innocua & $\frac{\underline{\text { Evrendilek and }}}{\text { Balasubramaniam }}$ \\
\hline Garlic & $\begin{array}{l}\text { Antibacteria } \\
1 \text {, food } \\
\text { preservative }\end{array}$ & Antibacterial effect in yogurt & E. coli, Staphylococcus aureus & $\frac{(\text { Nazari et al., }}{\underline{2019})}$ \\
\hline \multirow{3}{*}{ Cinnamon } & \multirow{2}{*}{$\begin{array}{l}\text { Antifungal, } \\
\text { food } \\
\text { preservative }\end{array}$} & $\begin{array}{l}\text { Extended shelf-life \&reduced } \\
\text { fungal disease incidence in } \\
\text { bananas }\end{array}$ & $\begin{array}{l}\text { Colletotrichum musae, E. coli, } \\
\text { S. Typhimurium, L. } \\
\text { monocytogenes }\end{array}$ & $\frac{\text { (Mehdi et al., }}{\underline{2010} \text { ) }}$ \\
\hline & & $\begin{array}{l}\text { Exhibited complete inhibitory } \\
\text { effect against pathogens of } \\
\text { pomegranate }\end{array}$ & $\begin{array}{l}\text { Botrytis sp., Penicillium sp., } \\
\text { Pilidiella granati }\end{array}$ & $\frac{\text { Munhuweyi et }}{\underline{\text { al., 2017) }}}$ \\
\hline & $\begin{array}{l}\text { Antibacteria } \\
1\end{array}$ & Bactericidal activity in milk & L. monocytogenes, E. coli & $\begin{array}{l}\text { (Cava-Roda et } \\
\underline{\text { al., 2012) }}\end{array}$ \\
\hline \multirow[t]{2}{*}{ Clove } & \multirow{2}{*}{$\begin{array}{l}\text { Antibacteria } \\
1, \text { food } \\
\text { preservative }\end{array}$} & $\begin{array}{l}\text { Inhibited bacterial growth in } \\
\text { milk, meat \& cheese }\end{array}$ & L. monocytogenes & $\begin{array}{l}\text { (Cava-Roda et } \\
\text { al., 2012; Menon } \\
\text { and Garg, 2001) }\end{array}$ \\
\hline & & $\begin{array}{l}\text { Inhibited bacterial growth in } \\
\text { low-fat } \& \text { full-fat soft cheese }\end{array}$ & L. monocytogenes, S. enteritidis & $\frac{\text { (Smith-Palmer et }}{\underline{\text { al., 2001) }}}$ \\
\hline \multirow[b]{2}{*}{ Eucalyptus } & Antifungal & $\begin{array}{l}\text { Controlled fungal pathogens in } \\
\text { passion fruits }\end{array}$ & $\begin{array}{l}\text { Alternaria spp., Fusarium spp., } \\
\text { Colletotrichum spp., } \\
\text { Penicillium spp. }\end{array}$ & $\frac{\text { (Waithaka et al., }}{\underline{2017} \text { ) }}$ \\
\hline & $\begin{array}{l}\text { Antiyeast } \\
\text { activity }\end{array}$ & $\begin{array}{l}\text { Inhibited development of yeast } \\
\text { in mixed fruit juice }\end{array}$ & $\begin{array}{l}\text { S. cerevisiae, Z. bailii, } A \text {. } \\
\text { pullulans, } C \text {. diversa, } P \text {. } \\
\text { fermentans, } P \text {. kluyveri, } P \text {. } \\
\text { anomala, } H . \text { polymorpha. }\end{array}$ & $\frac{\text { (Kumar Tyagi et }}{\underline{\text { al., 2014) }}}$ \\
\hline Mustard & Antifungal & $\begin{array}{l}\text { Inhibited fungi \& yeast growth } \\
\text { in bread }\end{array}$ & $\begin{array}{l}\text { Aspergillus flavus, Penicillium } \\
\text { commune, } P \text {. } \\
\text { roqueforti,Endomycesfibuliger }\end{array}$ & $\begin{array}{l}\text { (Nielsen and } \\
\underline{\text { Rios, 2000) }}\end{array}$ \\
\hline
\end{tabular}




\begin{tabular}{|c|c|c|c|c|}
\hline \multirow{2}{*}{ Tea tree } & Antifungal & $\begin{array}{l}\text { Reduced fungal growth of } \\
\text { cereal\&barley }\end{array}$ & $\begin{array}{l}\text { Fusarium graminearum, } \\
\text { Fusarium culmorum, } \\
\text { Pyrenophora graminea }\end{array}$ & $\frac{\text { (Terzi et al., }}{\underline{2007)}}$ \\
\hline & $\begin{array}{l}\text { Antimicrobi } \\
\text { al, food } \\
\text { preservative }\end{array}$ & $\begin{array}{l}\text { Inhibited microbial growth in } \\
\text { fresh cucumber juice }\end{array}$ & L. monocytogenes, E. coli. & (Shi et al., 2018) \\
\hline \multirow{3}{*}{ Nigella sativa } & $\begin{array}{l}\text { Antioxidant } \\
\text { antimicrobi } \\
\text { al, food } \\
\text { colorant }\end{array}$ & $\begin{array}{l}\text { Decresed bacterial counts in } \\
\text { dates pastes }\end{array}$ & $\begin{array}{l}\text { Enterobacteriaceae, } \\
\text { Staphylococcus } \\
\text { Aureus, Enterococcus faecalis }\end{array}$ & (Bahtiti) \\
\hline & $\begin{array}{l}\text { Antimicrobi } \\
\text { al }\end{array}$ & $\begin{array}{l}\text { Improved } \\
\text { physicochemical\&sensory } \\
\text { properties\& extended shelf-life } \\
\text { of domiati cheese }\end{array}$ & $\begin{array}{l}\text { Staphylococcus aureus, E.coli, } \\
\text { L. monocytogenes, S. enteritidis }\end{array}$ & $\frac{\text { (Mahgoub et al., }}{\underline{2013} \text { ) }}$ \\
\hline & $\begin{array}{l}\text { Antioxidant } \\
\text {, antifungal }\end{array}$ & $\begin{array}{lr}\text { Strong radical } & \text { scavenging } \\
\text { capacity\&fungal } & \text { growth } \\
\text { inhibition in rape seed oil }\end{array}$ & $\begin{array}{l}\text { Aspergillus ssp., Penicillium } \\
\text { citrinum, Fusarium } \\
\text { graminearum }\end{array}$ & $\frac{(\text { Singh et al., }}{\underline{2005})}$ \\
\hline
\end{tabular}

96 It is well established Nigella sativa has many nutritional and pharmaceutical uses.

97 Their seeds is considered to be an potential sources of edible food preservative and 98 antioxidant, and it was usually used in a variety of traditional foods such as tea, yogurt, 99 pickles, sauces, and salads, since the ancient Egyptians, Greeks, and Romans arena 100 (Benkaci-Ali et al., 2007; Hajhashemi et al., 2004; Venkatachallam et al., 2010). A 101 mixture of NSO with beeswax was reported to use for burns, skin infections, 102 moisturizers, joint pain reliever, or an anti-wrinkle agent (Badri et al., 2018). In addition, 103 some areas apply the oil externally, for beauty and skin diseases such as psoriasis and 104 eczema. Since long time, NSEO has been used as treatment of various diseases (e.g., 105 asthma, bronchitis, rheumatism, headaches, and dysentery) (Badri et al., 2018).

106 Meanwhile, lots of researchers explored NSEO biological properties, such as anti107 inflammatory, analgesic, immunomodulatory, spasmolytic, and anti-oxidant (Ali and 108 Blunden, 2003). Manju et al. (Manju et al., 2016) reported NSEO may be used as a 109 potential therapeutics against human lung cancer and control of pathogenic bacteria. In 110 addition, it was also shown that the NSEO has been used as a therapeutic agent to treat 111 headache, flatulence, blood hemostasis abnormalities, rheumatism, and related 7 
112 inflammatory diseases (Boulos and Gohary, 1983). The therapeutic potential of NSEO

113 is given in Fig. 2, and these outstanding properties may use as the functional food

114 products. According to the literature, thymoquinone is major bioactive compound in

115 black cumin essential oil related to most functional properties (Woo et al., 2012).

116 Several essential oil extracted from Nigella sativa and their antibacterial against

117 foodborne pathogens and antioxidant activity have been studied (Donsì et al., 2011;

118 Adamu et al., 2010; Sarwar and Latif, 2015). Indeed, the oil extracted from Nigella

119 sativa seeds has been proved with lower toxicity (Sultan et al., 2014). So, exploring

120 their valuable uses in food industry has attracted much attention.

121

122

123

124 4. The advantageous properties of Nigella sativa essential oil for food application

125 In the food industry, avoiding food oxidation and microbial spoilage in products are the

126 most important issues. Normally, to achieve this goal, using chemical synthetic

127 additives to reduce microbial growth and delay oxidation of products are conventional

128 methods. Nowadays, as consumer awareness increases, there is a growing concern of

129 the potential carcinogenic and mutagenic risks associated with chemical synthetic 
130 additives. In this sense, the development of alternative natural and low-toxic agents to

131 replace traditional synthetic substances (functional food additives) is of paramount

132 importance.

134 4.1. Antimicrobial Activity

135 The antibacterial activity of essential oil from plant are believed to come from phenolic

136 bioactive compounds (Hammer et al., 2000). NSEO comprising large amounts of

137 phenolic substances, such as $p$-cymene, thymol and carvacrol, which may be

138 responsible for its antimicrobial potential. Table 3 showed antibacterial activities

139 against both strains of its main constituents in NSEO and the results revealed

140 thymoquinone and longifolene had the highly active (Bourgou et al., 2010). NSEO

141 exhibited good antibacterial activity against Staphylococcus Aureus and Escherichia

142 coli with $\mathrm{IC}_{50}$ values of 12.0 and $62.0 \mu \mathrm{g} / \mathrm{ml}$ (Bourgou et al., 2010). Another study

143 indicated that Nigella sativa active substances exhibit considerable bactericidal activity

144 and prevent the growth and development of $\sim 90 \%$ of Staphylococcus aureus,

145 Staphylococcus epidermidis and Enterococcus faecalis (Chaieb et al., 2011). Sarwar

146 and Latif (Sarwar and Latif, 2015) found that NSO was more effective against

147 Salmonella species even than Ceftriaxone and Ciprofloxacin. Khosravi et al. (Khosravi

148 et al., 2011) evaluated the effects of NSEO against the growth and aflatoxins production

149 of $A$. parasiticus and results showed that NSEO had strong activity against $A$.

150 parasiticus (MIC90: 2.75; MFC: $6.25 \mathrm{mg} / \mathrm{mL}$ ). This study showed that NSEO can be

151 used as a natural inhibitor in low-level foods to protect food from fungal and toxin

152 contamination. Viuda-Martos et al. (Viuda-Martos et al., 2011) studied the effectiveness

153 of the Egyptian NSEO on three bacterial spices (Listeria, Pseudomonas, and Serratia)

154 and they found it only against L. innocua (inhibition zones of $31.00 \mathrm{~mm}$ ). Jrah Harzallah

155 (Jrah Harzallah et al., 2011) compared the antibacterial properties of the Tunisian NSEO

156 and its bioactive compounds (Thymoquinone). The results showed the NSEO has a

157 strong antibacterial activity against S. mitis, S. mutans, S. constellatus and G.

158 haemolysans $(\mathrm{MIC}=2.13 \mathrm{mg} / \mathrm{ml})$ than only used thymoquinone, which mean the 
159 different compounds in the essential oil working in a synergistic manner. This

160 emphasizes the importance of using whole oil (or crude extract) of seeds in

161 pharmacological research.

162

163

164

Table 3. Antibacterial activities of Nigella sativa essential oil and its main constituents.(Bourgou et al., 2010)

\begin{tabular}{lll}
\hline Tested compounds & S. aureus & E. coli \\
\hline Nigella sativaessential oil & $12.0 \pm 4.0^{\mathrm{a}}$ & $62.0 \pm 17.0^{\underline{\mathrm{a}}}$ \\
$p$-Cymene & $>100^{\mathrm{b}}$ & $>100^{\mathrm{b}}$ \\
$\gamma$-Terpinene & $>100^{\mathrm{b}}$ & $>100^{\mathrm{b}}$ \\
Thymoquinone & $1.8 \pm 0.6^{\mathrm{b}}$ & $41.0 \pm 19.0^{\mathrm{b}}$ \\
$\beta$-Pinene & $>100^{\mathrm{b}}$ & $>100^{\mathrm{b}}$ \\
Carvacrol & $>100^{\mathrm{b}}$ & $>100^{\mathrm{b}}$ \\
Terpinen-4-ol & $>100^{\mathrm{b}}$ & $>100^{\mathrm{b}}$ \\
Longifolene & $3.0 \pm 1.0^{\mathrm{b}}$ & $>100^{\mathrm{b}}$ \\
Chloramphenicol & $7.0 \pm 1.0^{\mathrm{b}}$ & $0.8 \pm 0.1^{\mathrm{b}}$ \\
\hline
\end{tabular}

165

Chloramphenicol was used as positive control. Values are mean \pm S.D..

166

167

168

169

170

171

172

173

174

175

176

177

178

\subsection{Antioxidant Activity}

Lipid oxidation is a crucial factor affecting food quality during food processing, marketing and storage. In the past decade, the antioxidant activity of Nigella sativa seeds and NSEO had been widely investigated (Adamu et al., 2010). Table 4 shown antioxidant activities of its main constituents in NSEO by DCFH-DA assay and they confirmed that the in vivo antioxidant activity of the essential oil is mainly due to the action of thymoquinone (Bourgou et al., 2010). It is reported that carvacrol and thymol in NSEO also contribute to antioxidant activity in vitro (Houghton et al., 1995). As reported by Cascella et al. (Cascella et al., 2018), Nigella sativa could be a useful compound for preventing and treating cerebral ischemic and neurodegenerative diseases, due to it have significant anti-oxidant effect and could represent effective neuroprotective activity. In addition, Viuda-Martos (Viuda-Martos et al., 2011) 
compared antioxidant properties of five essential oil of the species widely cultivated in

180 Egypt. Accordingly, they found that, black cumin oil has the strongest antioxidant

181 activity $(\mathrm{p}<0.05)$ and its free radical scavenging was $95.89 \%$ at $50 \mathrm{mg} / \mathrm{mL}$. Sultan et

182 al. (Sultan et al., 2009) studied fixed and essential oil from Nigella sativa and they

183 found NSEO (80.25\%) showed significant higher antioxidant capacity than fixed oil

$184(32.32 \%)$ by the experiments of DPPH radical scavenging. Based on Erkan, Ayranci's

185 results, NSEO inhibited DPPH radical formation and mean the value of $\mathrm{IC}_{50}(\mu \mathrm{M})$ was

186 found to be $515 \pm 20.1$ (Erkan et al., 2008). Another experiments about NSEO, the value

187 of $\mathrm{IC}_{50}$ value of thymoquinone and carvacrol tested by DPPH assay were found to be

$188460.0,211.0$ and $28.8 \mathrm{mg} / \mathrm{mL}$, respectively (Burits and Bucar, 2000).

Table 4. Antioxidant activities of Nigella sativa essential oil and its main constituents. (Bourgou et al.,

\begin{tabular}{|c|c|}
\hline \multicolumn{2}{|r|}{ 2010) } \\
\hline Tested compounds & Inhibition of DCFH oxidation \\
\hline Nigella sativaessential oil & $1.0 \pm 1.0^{\mathrm{a}}$ \\
\hline$p$-Cymene & $>200^{\underline{b}}$ \\
\hline$\gamma$-Terpinene & $>200^{\underline{b}}$ \\
\hline Thymoquinone & $1.0 \pm 0.8^{\mathrm{b}}$ \\
\hline$\beta$-Pinene & $>200^{\underline{b}}$ \\
\hline Carvacrol & $190.0 \pm 60.0^{\mathrm{b}}$ \\
\hline Terpinen-4-ol & $>200^{\underline{b}}$ \\
\hline Longifolene & $>200^{\underline{b}}$ \\
\hline Quercetin & $0.1 \pm 0.1^{\underline{b}}$ \\
\hline
\end{tabular}

192 193

194

195

196

197

Quercetin was used as positive control. Values are mean \pm S.D. A= $\mathrm{IC}_{50}$ values $(\mu \mathrm{g} / \mathrm{ml}) ; \mathrm{b}=\mathrm{IC}_{50}$ values $(\mu \mathrm{M})$.

\subsection{Nutritional value}

As an edible and medicinal plant, Nigella sativa is generally to take in numerous forms, such as spice, fruit, or food ingredient. In different types of meals, NSEO as a bread or cheese flavoring and spice is employed. According to the report (Ahmad et al., 2013), Nigella sativa seeds contain protein (26\%), carbohydrates $(25 \%)$, crude fiber $(8.4 \%)$, 11 
ash (4.8\%) with large amounts of carotene and minerals $(\mathrm{Cu}, \mathrm{P}, \mathrm{Zn}$ and $\mathrm{Fe})$ (Table. 5),

201 such as copper, phosphorus, zinc and iron. Tulukcu (Tulukcu, 2011) indicated that the

202 crude oil extracted from Nigella sativa is considered a functional oil due to its rich

203 content of omega-6 and omega-9 fatty acids including linoleic (54.0-70.0\%) and oleic

$204 \quad(15.0-24.0 \%)$, respectively.

Table 5. Principal nutrients of Nigella sativa

\begin{tabular}{lc}
\hline Compound & Quantity (\%) \\
\hline Protein & 26 \\
Carbohydrates & 25 \\
Crude fiber & 8.4 \\
Ash & 4.8 \\
\hline
\end{tabular}

208 Meanwhile, there was very low toxicity of NSO have been observed in rat and mice 209 (Zaoui et al., 2002). Mahmoudv (ㅂ. Mahmoudvand et al., 2014a) evaluated the 210 cytotoxic effects of various extracts of NSEO and thymoquinone on murine 211 macrophages by MTT assay and they observed a dose-dependent response with 212 increasing concentrations. In this stage, NSEO showed a less cytotoxic effect on murine 213 macrophages and the value of $\mathrm{C}_{50}$ was $641.6 \pm 5.1 \mu \mathrm{g} / \mathrm{mL}$, while thymoquinone as the 214 active constituent showed higher cytotoxic effect $\left(\mathrm{C}_{50}=36.3 \mu \mathrm{g} / \mathrm{mL}\right)$. In another study, 215 Dollah et al. (Dollah et al., 2013) studied the toxicity of Nigella sativa powder on liver 216 function, but they did not see significant changes in liver enzyme blood levels. The 217 same result was reported by Khader (Khader et al., 2009) who extracted NSO with no 218 significant side effects on liver or kidney function. Zaoui, Cherrah et al (Zaoui et al., 219 2002) also confirmed the low toxicity of NSO by high $\mathrm{LD}_{50}$ values, and suggested a 220 wide margin of safety for therapeutic doses of NSO From the above results, it can be 221 concluded that Nigella sativa and its extracts oils are comparatively safe as a dietary 222 supplement or a remedy for drugs, but there is still lack of systematic evaluation. 


\section{Stability of the Nigella sativa oil}

225 Oxidation is a big problem in NSO during food processing, marketing and storage since 226 these oils are sensitive to oxidation. Oxidation not only deteriorates the taste and aroma 227 of the oils but also leads to formation of hazardous compounds. Literature has reported 228 that the progress of lipid oxidation of edible oils is influenced by many factors such as 229 light, heat treatment, oxygen availability and the presence of antioxidants 230 (Grosshagauer et al., 2019). Thus, the mechanism and prevention method of oxidation 231 must be considered. Lipid oxidation of NSO is a complex chemical reaction sequence 232 that is prone to enzymatic and non-enzymatic oxidative degradation. The happening of 233 enzymatic oxidation (hydrolysis) of oil typically requires the presence of water and 234 enzymes (such as lipoxygenases, esterase and cyclooxygenases) in the oil phase and the 235 enzymatic oxidation will lead to the production of hydro-peroxides, which may cause 236 cell damage (Ahmed et al., 2016). Non-enzymatic oxidation can be divided into auto237 oxidation and photo-oxidation. According to the Choe and Min's report (Choe and Min, 238 2006), auto-oxidation is mediated by autocatalytic formation and reaction of free 239 radicals (radical forms of acylglycerols) or triplet oxygen $\left({ }^{3} \mathrm{O}_{2}\right)$ with oils, whereas the 240 photo-oxidation is mediated by ultraviolet or singlet oxygen $\left({ }^{1} \mathrm{O}_{2}\right)$. The automatic 241 oxidation of NSO could be accelerated by free fatty acids, metals such as iron, 242 monoacylglycerols and diacylglycerols, and thermo-oxidic compounds. Study from 243 Mohammed, Meor Hussin et al. (Mohammed et al., 2017a), they pointed out that NSO 244 is susceptible to oxidative degradation and the peroxide value $(78.57 \pm 0.22 \mathrm{mEq} \mathrm{O} / \mathrm{kg}$ 245 oil) of NSO showed significant increases with 24 days. Similar finding was reported by 246 Ramadan et al. (Mohamed Fawzy Ramadan and Mörsel, 2004), who reported that NSO 247 showed increasing in the peroxide value up to $64.5 \mathrm{mEq} \mathrm{O} / 2 \mathrm{~kg}$ after 21 days. On the 248 other hand, NSO will oxidize degradation and NSEO will volatilize during storage. 249 Fortunately, these challenges of using NSO can be overcooked to some extent by 250 suitable encapsulation technology.

252 6. Encapsulation of Nigella Sativa essential oil and their potential applications in 
254 NSO is rich in monounsaturated fatty acids (very sensitive to oxidation). A small 255 amount of essential oil (NSEO) in NSO should also be prevented from volatilization. 256 Besides that, there are some problems with low solubility and weird smell that cannot 257 be fully applied. Luckily, the incorporation of NSO or NSEO into in a shell of wall 258 material for protection can significantly improve physical properties, such as 259 dispersibility, solubility, turbidity, viscosity, and thus promote bioactivity, in 260 comparison with the free NSO (Blanco-Padilla et al., 2014).

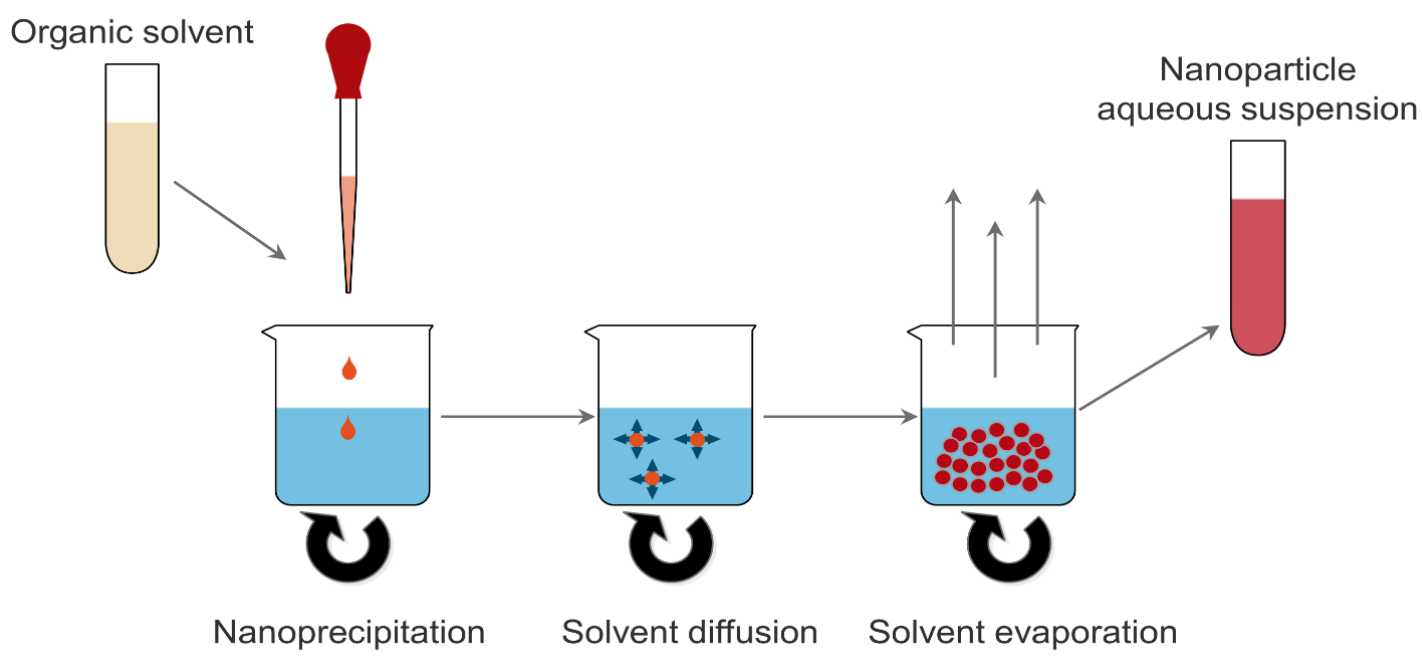

Fig. 3. Nanoprecipitation method (Tarhini et al., 2017).

264 Some encapsulation systems studied about NSO and its main founding are listed in 265 Table 5. For the food industry, nowadays, various technologies for the encapsulation of 266 bioactive compounds have been investigated; however, only a few techniques, namely 267 spray drying and freeze drying, could be used in the food industries (de Souza Simões 268 et al., 2017), because of its high efficiency, low cost and suitable equipment that is 269 readily available (Dobry et al., 2009). Meanwhile, there are also some other ways to 270 encapsulate NSO at laboratory scale, such as nanoprecipitation (Badri et al., 2018), 271 high-energy methods (Periasamy et al., 2016; Sharif et al., 2017) and layer-by-layer 272 (LbL) (Fig. 4) (Konuk Takma and Korel, 2019). 


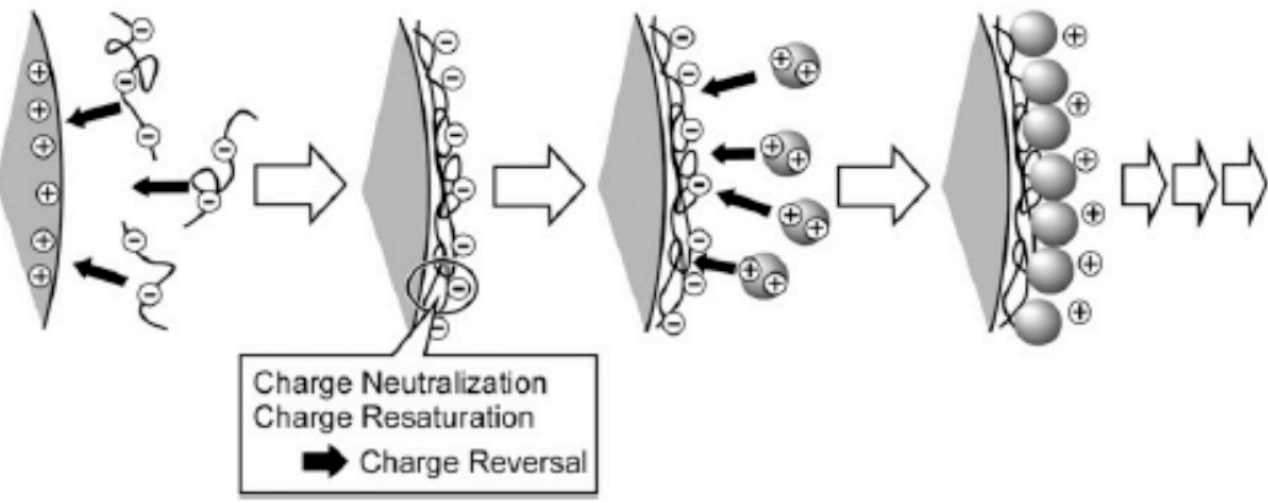

274

Fig. 4 Layer by layer method (Miladi et al., 2014)

Spray drying (Fig. 5) is the most common and economically practicable method used in the manufacture of powdered form for food applications (Carneiro et al., 2013). In general, there are three main steps in the spray drying process for microencapsulation: preparation of the dispersion, homogenization of the emulsion and atomization of material into the drying chamber (Gharsallaoui et al., 2007). The wall material content, oil concentration, ratio, and spray dried inlet air temperature are the main parameters effecting the final encapsulated powder (Jafari et al., 2008). Mohammed, Tan et al. (Mohammed et al., 2017b) investigated the effect of process conditions on the microencapsulation of spray-dried NSO by the response surface methodology (RSM). Their results show that lipid oxidation of NSO could be significantly reduced by optimizing the microencapsulation conditions. The highest encapsulation efficiency reached 92.71\%. Edris, Kalemba et al. (Edris et al., 2016) also used spray drying technique to encapsulate Nigella sativa oleoresin into the powder. The results showed that encapsulation efficiency of the volatile oil fraction reached $86.2 \%$, which mean that it can be used in the manufacture of foods and nutraceuticals. There are some other techniques to encapsulate NSEO. Sharif, et al. (Sharif et al., 2017) used different ratios of NSEO with modified starch, under high speed homogenization, to formulate nanoemulsion. The nanoemulsion exhibited monomodal size distributions with mean droplet diameter below $200 \mathrm{~nm}$ and showed stability against phase separation and coalescence for 4 weeks storage at room temperature. Badri, et al (Badri et al., 2018) 
used nanoprecipitation method (see Fig. 3) to design NSO nanocapsule by nanoprecipitation. The results showed that the size of the prepared nanoparticles did not

299 change significantly within 30 days of the stability study (change interval 250-270 nm).

300 Negut, et al. (Negut et al., 2018) prepared $\mathrm{Fe}_{3} \mathrm{O}_{4}$ nanoparticles containing NSO by co301 precipitation method in $\mathrm{NH}_{4} \mathrm{OH}$ solution.

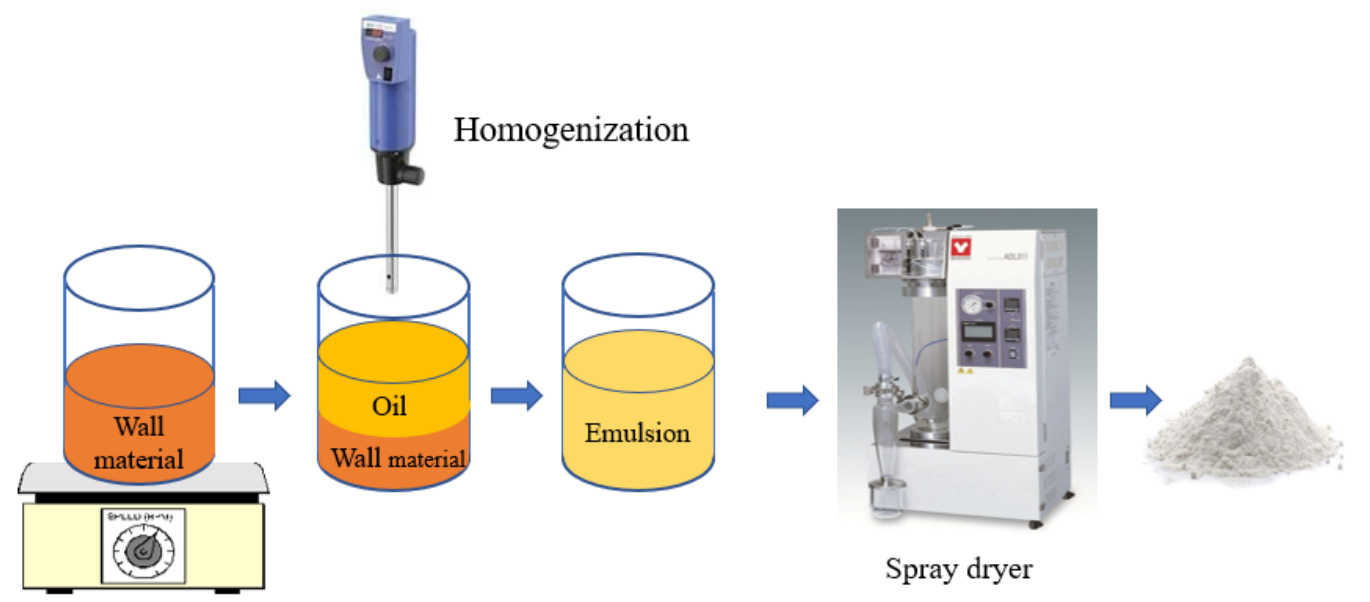

Fig. 5. The process diagram of spray drying.

305 In brief, given excellent physical properties of NSEO after encapsulation, they have the 306 potential to be used in novel food products as a food preservative, antioxidant in 307 different forms (emulsion, powder and packaging, etc). Konuk Takma and Korel 308 (Konuk Takma and Korel, 2019) prepared the film by antimicrobial chitosan and 309 alginate containing NSO and investigated the effect of NSO packaging film on the 310 quality and shelf-life of chicken breast meats stored at $4{ }^{\circ} \mathrm{C}$ for 5 days. The results 311 showed that the samples stored in the active packaging had Lower Total Aerobic 312 Mesophilic (TAMC) and Psychrotrophic Bacteria Counts (PBC) in compare with the 313 control group. Shaaban, Sadek et al. (Shaaban et al., 2015) prepared water-based 314 microemulsion system containing NSEO and its antibacterial activity against six 315 pathogenic bacteria was evaluated. Results showed that NSEO microemulsion was 316 highly effective against $S$. aureus, B. cereus and $S$. typhimurium even at the lowest 317 tested concentration (100.0 $\mu \mathrm{g} /$ well). Sharif, et al. (Sharif et al., 2017) indicated 
318 encapsulated NSEO showed higher bactericidal activity against two Gram positive

319 pathogenic bacterial strains as compared to pure NSEO. Abedi, Rismanchi et al. (Abedi

320 et al., 2016) found out that NSO microcapsules can be employed to produce functional

321 yogurt because of its high stability, proper chemical and sensory properties. Despite this

322 fact, there are still only a few studies carried out to reveal their potential application as

323 functional food products.

324

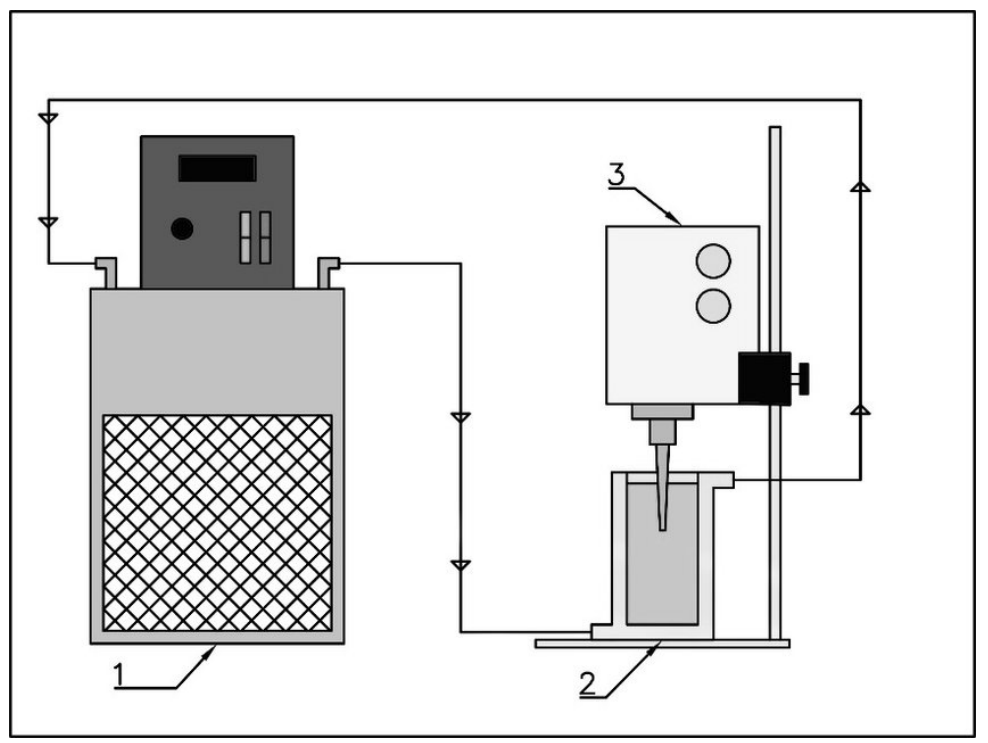

326 Fig. 6. Ultrasonication experimental setup. 1) cooled circulation bath, 2) double wall container, 3)

ultrasonic probe (Martínez et al., 2018).

328

329

Table 6. Recently encapsulated Nigella Sativa oil, Nigella Sativa essential oil and Thymoquinone

\begin{tabular}{|c|c|c|c|c|c|}
\hline Core material & $\begin{array}{l}\text { Encapsulation } \\
\text { techniques }\end{array}$ & Wall materials & Forms & Main conclusions & References \\
\hline NSEO & Emulsification & Tween 20 & $\begin{array}{l}\text { Microemuls } \\
\text { ion }\end{array}$ & $\begin{array}{l}\text { The EO emulsion was more effective } \\
\text { than eugenol emulsion against } S \text {. } \\
\text { aureus, E. coli, B. cereus, } L \text {. } \\
\text { monocytogens }\end{array}$ & $\begin{array}{l}\text { (Shaaban et } \\
\text { al., 2015) }\end{array}$ \\
\hline NSEO & $\begin{array}{l}\text { High speed } \\
\text { homogenization }\end{array}$ & Modified starch & $\begin{array}{l}\text { Nano- } \\
\text { emulsions }\end{array}$ & $\begin{array}{l}\text { Emulsions showed shear thinning } \\
\text { phenomena and stability towards } \\
\text { coalescence during storage ( } 4 \text { weeks } \\
\text { at } 25^{\circ} \mathrm{C} \text { ) }\end{array}$ & $\begin{array}{l}\text { (Sharif et } \\
\text { al., 2017) }\end{array}$ \\
\hline NSEO & $\begin{array}{l}\text { Layer-by-layer } \\
\text { (LbL) }\end{array}$ & $\begin{array}{l}\text { Alginate and } \\
\text { chitosan }\end{array}$ & Film & $\begin{array}{l}\text { Results indicated that active film } \\
\text { containing NSEO has the potential to } \\
\text { maintain safety and quality of } \\
\text { chicken meat. }\end{array}$ & $\frac{\text { (Konuk }}{\frac{\text { Takma and }}{\text { Korel, }}}$ \\
\hline
\end{tabular}


Nanoprecipitati on

Poly $(\varepsilon-$ caprolactone)

Nanoparticl
es

NSEO were successfully encapsulated that would boost the anti-inflammatory and analgesic effects of indomethacin.

Sodium caseinate

NSO

Spray drying

DE10

Powder

The application of

microencapsulation had a significant protection effect on the oil oxidation

(Tarhini et al., 2017)

NSO

Ultrasonication

(Fig. 6)

Whey proteins

Emulsion

Emulsion droplets keep stable at least 8 days upon storage at $4 \pm 2{ }^{\circ} \mathrm{C}$

(Anandan

Encapsulated NSO showed increased stability and resistance content of

Maltodextrin DE10

NSO

Spray drying

and sodium

caseinate

Powder

bioactive compounds, and

antioxidant activity, as well as

changes in fatty acid composition

than un-encapsulated NSO

The results of chemical and sensory

analysis suggest that NSO

microcapsules can be used for

producing functional yogurt

The powder, which encapsulates a functional oleoresin, can be used in fortification of different processed

foods, dairy or nutraceutical

(Edris et products.

Nanoparticl es

PLGA encapsulated TQ nanoparticle with sustained release property has preserved antioxidant as well as antimicrobial activity

(Abedi et al., 2016)

NLCs could be a promising vehicle for the oral delivery of TQ and improve its gastroprotective properties
(Nallamuth

u et al., $\underline{2013)}$

(Abdelwah ab et al., $\underline{2013)}$

331 7. Conclusion

332 Interest in new sources of oil seeds has recently grown. This chapter conclude that

333 among the various oil seeds, NSEO containing several phytochemicals that has been

334 considered all over the world for having a positive impact on human health. Particularly,

335 essential oil in Nigella sativa displays considerable commercial value thanks to its

336 strong antimicrobial and antioxidant activities. These outstanding properties of NSEO

337 have potential to play a remarkable role as a novel source of food preservative or 
338 antioxidants. However, there are still some physical shortcomings like lipid oxidation,

339 low water solubility and volatility. The recent advancement in encapsulation, offers the 340 great opportunity to design novel carriers to deliver NSEO and to control its release. 341 Therefore, further research is needed to be conducted to find new applications of 342 Nigella sativa and to transfer NSEO encapsulation from laboratory-scale to industrial 343 scale. 
345 Abdelwahab, S. I., Sheikh, B. Y., Taha, M. M. E., How, C. W., Abdullah, R., Yagoub, U., et al. (2013). Thymoquinone-loaded nanostructured lipid carriers: preparation, gastroprotection, in vitro toxicity, and pharmacokinetic properties after extravascular administration. International journal of nanomedicine, 8 , 2163. Abedi, A. S., Rismanchi, M., Shahdoostkhany, M., Mohammadi, A., \& Hosseini, H. (2016). Microencapsulation of Nigella sativa seeds oil containing thymoquinone by spray-drying for functional yogurt production. International journal of food science \& technology, 51(10), 2280-2289. Adamu, H. M., Ekanem, E., \& Bulama, S. (2010). Identification of essential oil components from Nigella sativa seed by gas chromatography-mass spectroscopy. Pakistan Journal of Nutrition, 9(10), 966-967. Aggarwal, B. B., \& Kunnumakkara, A. B. (2009). Molecular targets and therapeutic uses of spices: modern uses for ancient medicine. World Scientific. Ahmad, A., Husain, A., Mujeeb, M., Khan, S. A., Najmi, A. K., Siddique, N. A., et al. (2013). A review on therapeutic potential of Nigella sativa: A miracle herb. Asian Pacific journal of tropical biomedicine, 358 3(5), 337-352.

359 Ahmed, M., Pickova, J., Ahmad, T., Liaquat, M., Farid, A., \& Jahangir, M. (2016). Oxidation of Lipids 360 in Foods. Sarhad Journal of Agriculture, 32(3).

361 Ali, B., \& Blunden, G. (2003). Pharmacological and toxicological properties of Nigella sativa. 362 Phytotherapy Research: An international journal devoted to pharmacological and toxicological 363 evaluation of natural product derivatives, 17(4), 299-305.

364 Anandan, S., Keerthiga, M., Vijaya, S., Asiri, A. M., Bogush, V., \& Krasulyaa, O. (2017). 365 Physicochemical characterization of black seed oil-milk emulsions through ultrasonication. Ultrasonics 366 Sonochemistry, 38, 766-771..

367 Badia, V., de Oliveira, M. S. R., Polmann, G., Milkievicz, T., Galvão, A. C., \& da Silva Robazza, W. (2019). Effect of the addition of antimicrobial oregano (Origanum vulgare) and rosemary (Rosmarinus officinalis) essential oils on lactic acid bacteria growth in refrigerated vacuum-packed Tuscan sausage. Brazilian Journal of Microbiology, 1-13.

371 Badri, W., El Asbahani, A., Miladi, K., Baraket, A., Agusti, G., Nazari, Q. A., et al. (2018). Poly (ع372 caprolactone) nanoparticles loaded with indomethacin and Nigella sativa L. essential oil for the topical treatment of inflammation. Journal of Drug Delivery Science and Technology, 46, 234-242. Bahtiti, N. H. A. Chemical Investigation and Preservative Effect of Jordanian Nigella Sativa L. Seed Oil on Date Paste.

Benkaci-Ali, F., Baaliouamer, A., Meklati, B. Y., \& Chemat, F. (2007). Chemical composition of seed essential oils from Algerian Nigella sativa extracted by microwave and hydrodistillation. Flavour and fragrance journal, 22(2), 148-153.

Blanco-Padilla, A., Soto, K. M., Hernández Iturriaga, M., \& Mendoza, S. (2014). Food antimicrobials

381 Bosquez-Molina, E., Ronquillo-de Jesús, E., Bautista-Baños, S., Verde-Calvo, J., \& Morales-López, J. 382 (2010). Inhibitory effect of essential oils against Colletotrichum gloeosporioides and Rhizopus stolonifer 383 in stored papaya fruit and their possible application in coatings. Postharvest Biology and Technology, 384 57(2), 132-137.

385 Boulos, L., \& Gohary, M. (1983). Medicinal plants of north Africa.

386 Bourgou, S., Pichette, A., Marzouk, B., \& Legault, J. (2010). Bioactivities of black cumin essential oil 
and its main terpenes from Tunisia. South African Journal of Botany, 76(2), 210-216..

Burits, M., \& Bucar, F. (2000). Antioxidant activity of Nigella sativa essential oil. Phytotherapy research, 389 14(5), 323-328.

390 Carneiro, H. C., Tonon, R. V., Grosso, C. R., \& Hubinger, M. D. (2013). Encapsulation efficiency and 391 oxidative stability of flaxseed oil microencapsulated by spray drying using different combinations of wall 392 materials. Journal of Food Engineering, 115(4), 443-451.

393 Cascella, M., Bimonte, S., Barbieri, A., Del Vecchio, V., Muzio, M. R., Vitale, A., et al. (2018). Dissecting 394 the potential roles of Nigella sativa and its constituent Thymoquinone on the prevention and on the 395 progression of Alzheimer's disease. Frontiers in aging neuroscience, 10, 16.

396 Cava-Roda, R. M., Taboada-Rodríguez, A., Valverde-Franco, M. T., \& Marín-Iniesta, F. (2012). 397 Antimicrobial activity of vanillin and mixtures with cinnamon and clove essential oils in controlling 398 Listeria monocytogenes and Escherichia coli O157: H7 in milk. Food and Bioprocess Technology, 5(6), $3992120-2131$.

400 Chaieb, K., Kouidhi, B., Jrah, H., Mahdouani, K., \& Bakhrouf, A. (2011). Antibacterial activity of 401 Thymoquinone, an active principle of Nigella sativa and its potency to prevent bacterial biofilm 402 formation. BMC complementary and alternative medicine, 11(1), 29.

403 Choe, E., \& Min, D. B. (2006). Mechanisms and factors for edible oil oxidation. Comprehensive reviews 404 in food science and food safety, 5(4), 169-186.

405 Chouliara, E., Karatapanis, A., Savvaidis, I., \& Kontominas, M. (2007). Combined effect of oregano 406 essential oil and modified atmosphere packaging on shelf-life extension of fresh chicken breast meat, 407 stored at 4 C. Food Microbiology, 24(6), 607-617.

408 D'Antuono, L. F., Moretti, A., \& Lovato, A. F. S. (2002). Seed yield, yield components, oil content and 409 essential oil content and composition of Nigella sativa L. and Nigella damascena L. Industrial Crops and 410 Products, 15(1), 59-69.

411 de Medeiros Barbosa, I., da Costa Medeiros, J. A., de Oliveira, K. Á. R., Gomes-Neto, N. J., Tavares, J. 412 F., Magnani, M., et al. (2016). Efficacy of the combined application of oregano and rosemary essential 413 oils for the control of Escherichia coli, Listeria monocytogenes and Salmonella Enteritidis in leafy 414 vegetables. Food control, 59, 468-477.

415 de Souza Simões, L., Madalena, D. A., Pinheiro, A. C., Teixeira, J. A., Vicente, A. A., \& Ramos, O. L. 416 (2017). Micro-and nano bio-based delivery systems for food applications: In vitro behavior. Advances in 417 Colloid and Interface Science, 243, 23-45.

418 Dobry, D. E., Settell, D. M., Baumann, J. M., Ray, R. J., Graham, L. J., \& Beyerinck, R. A. (2009). A 419 model-based methodology for spray-drying process development. Journal of pharmaceutical innovation, 420 4(3), 133-142.

421 Dollah, M. A., Parhizkar, S., Latiff, L. A., \& Hassan, M. H. B. (2013). Toxicity effect of Nigella sativa 422 on the liver function of rats. Advanced pharmaceutical bulletin, 3(1), 97.

423 Donsì, F., Annunziata, M., Sessa, M., \& Ferrari, G. (2011). Nanoencapsulation of essential oils to enhance 424 their antimicrobial activity in foods. LWT-Food Science and Technology, 44(9), 1908-1914.

425 Edris, A. E., Kalemba, D., Adamiec, J., \& Piątkowski, M. (2016). Microencapsulation of Nigella sativa 426 oleoresin by spray drying for food and nutraceutical applications. Food Chemistry, 204, 326-333..

427 Emiroğlu, Z. K., Yemiş, G. P., Coşkun, B. K., \& Candoğan, K. (2010). Antimicrobial activity of soy 428 edible films incorporated with thyme and oregano essential oils on fresh ground beef patties. Meat 429 science, 86(2), 283-288.

430 Erkan, N., Ayranci, G., \& Ayranci, E. (2008). Antioxidant activities of rosemary (Rosmarinus Officinalis 
431 L.) extract, blackseed (Nigella sativa L.) essential oil, carnosic acid, rosmarinic acid and sesamol. Food 432 chemistry, 110(1), 76-82.

433 Evrendilek, G. A., \& Balasubramaniam, V. (2011). Inactivation of Listeria monocytogenes and Listeria

434 innocua in yogurt drink applying combination of high pressure processing and mint essential oils. Food

435 Control, 22(8), 1435-1441.

436 Ferdous, A., Islam, S., Ahsan, M., Hasan, C., \& Ahmed, Z. (1992). In vitro antibacterial activity of the

437 volatile oil of Nigella sativa seeds against multiple drug-resistant isolates of Shigella spp. and isolates of

438 Vibrio cholerae and Escherichia coli. Phytotherapy Research, 6(3), 137-140.

439 Gündüz, G. T., Gönül, Ş. A., \& Karapınar, M. (2010). Efficacy of oregano oil in the inactivation of

440 Salmonella typhimurium on lettuce. Food Control, 21(4), 513-517.

441 George, D., Smith, T., Shiel, R., Sparagano, O., \& Guy, J. (2009). Mode of action and variability in

442 efficacy of plant essential oils showing toxicity against the poultry red mite, Dermanyssus gallinae.

443 Veterinary parasitology, 161(3-4), 276-282.

444 Gharsallaoui, A., Roudaut, G., Chambin, O., Voilley, A., \& Saurel, R. (2007). Applications of spray-

445 drying in microencapsulation of food ingredients: An overview. Food research international, 40(9),

$446 \quad 1107-1121$.

447 Govaris, A., Botsoglou, E., Sergelidis, D., \& Chatzopoulou, P. S. (2011). Antibacterial activity of oregano

448 and thyme essential oils against Listeria monocytogenes and Escherichia coli O157: H7 in feta cheese

449 packaged under modified atmosphere. LWT-Food Science and Technology, 44(4), 1240-1244.

450 Govaris, A., Solomakos, N., Pexara, A., \& Chatzopoulou, P. (2010). The antimicrobial effect of oregano

451 essential oil, nisin and their combination against Salmonella Enteritidis in minced sheep meat during

452 refrigerated storage. International journal of food microbiology, 137(2-3), 175-180.

453 Grosshagauer, S., Steinschaden, R., \& Pignitter, M. (2019). Strategies to increase the oxidative stability

454 of cold pressed oils. $L W T, 106,72-77$.

455 Gutierrez, J., Rodriguez, G., Barry-Ryan, C., \& Bourke, P. (2008). Efficacy of plant essential oils against

456 foodborne pathogens and spoilage bacteria associated with ready-to-eat vegetables: antimicrobial and

457 sensory screening. Journal of food protection, 71(9), 1846-1854.

458 Hajhashemi, V., Ghannadi, A., \& Jafarabadi, H. (2004). Black cumin seed essential oil, as a potent

459 analgesic and antiinflammatory drug. Phytotherapy Research: An International Journal Devoted to

460 Pharmacological and Toxicological Evaluation of Natural Product Derivatives, 18(3), 195-199.

461 Hammer, K. A., Carson, C. F., \& Riley, T. V. (2000). Melaleuca alternifolia (tea tree) oil inhibits germ

462 tube formation by Candida albicans. Medical Mycology, 38(5), 355-362.

463 Hasapidou, A., \& Savvaidis, I. (2011). The effects of modified atmosphere packaging, EDTA and oregano

464 oil on the quality of chicken liver meat. Food Research International, 44(9), 2751-2756.

465 Houghton, P. J., Zarka, R., de las Heras, B., \& Hoult, J. (1995). Fixed oil of Nigella sativa and derived

466 thymoquinone inhibit eicosanoid generation in leukocytes and membrane lipid peroxidation. Planta

467 medica, 61(01), 33-36.

468 Jafari, S. M., Assadpoor, E., He, Y., \& Bhandari, B. (2008). Encapsulation efficiency of food flavours 469 and oils during spray drying. Drying Technology, 26(7), 816-835.

470 Jrah Harzallah, H., Kouidhi, B., Flamini, G., Bakhrouf, A., \& Mahjoub, T. (2011). Chemical composition,

471 antimicrobial potential against cariogenic bacteria and cytotoxic activity of Tunisian Nigella sativa

472 essential oil and thymoquinone. Food Chemistry, 129(4), 1469-1474.

473 Kanter, M. (2008). Nigella sativa and derived thymoquinone prevents hippocampal neurodegeneration

474 after chronic toluene exposure in rats. Neurochemical research, 33(3), 579. 
Karabagias, I., Badeka, A., \& Kontominas, M. (2011). Shelf life extension of lamb meat using thyme or oregano essential oils and modified atmosphere packaging. Meat science, 88(1), 109-116.

Khader, M., Bresgen, N., \& Eckl, P. (2009). In vitro toxicological properties of thymoquinone. Food and Chemical Toxicology, 47(1), 129-133.

Khan, M. T. H., \& Ather, A. (2006). Lead molecules from natural products: discovery and new trends. Elsevier.

Khosravi, A. R., Shokri, H., \& Minooeianhaghighi, M. (2011). Inhibition of aflatoxin production and growth of Aspergillus parasiticus by Cuminum cyminum, Ziziphora clinopodioides, and Nigella sativa essential oils. Foodborne pathogens and disease, 8(12), 1275-1280.

Konuk Takma, D., \& Korel, F. (2019). Active packaging films as a carrier of black cumin essential oil: Development and effect on quality and shelf-life of chicken breast meat. Food Packaging and Shelf Life, 19, 210-217.

Kumar Tyagi, A., Bukvicki, D., Gottardi, D., Tabanelli, G., Montanari, C., Malik, A., et al. (2014). Eucalyptus essential oil as a natural food preservative: in vivo and in vitro antiyeast potential. BioMed research international, 2014.

Mahgoub, S. A., Ramadan, M. F., \& El-Zahar, K. M. (2013). Cold Pressed N igella sativa Oil Inhibits the Growth of Foodborne Pathogens and Improves the Quality of Domiati Cheese. Journal of Food Safety, 33(4), 470-480.

Mahmoudvand, H., Sepahvand, A., Jahanbakhsh, S., Ezatpour, B., \& Ayatollahi Mousavi, S. A. (2014a). Evaluation of antifungal activities of the essential oil and various extracts of Nigella sativa and its main component, thymoquinone against pathogenic dermatophyte strains. Journal de Mycologie Médicale, 24(4), e155-e161.

Mahmoudvand, H., Sepahvand, A., Jahanbakhsh, S., Ezatpour, B., \& Mousavi, S. A. (2014b). Evaluation of antifungal activities of the essential oil and various extracts of Nigella sativa and its main component, thymoquinone against pathogenic dermatophyte strains. Journal de mycologie medicale, 24(4), e155e161.

Manju, S., Malaikozhundan, B., Vijayakumar, S., Shanthi, S., Jaishabanu, A., Ekambaram, P., et al. (2016). Antibacterial, antibiofilm and cytotoxic effects of Nigella sativa essential oil coated gold nanoparticles. Microbial Pathogenesis, 91, 129-135.

Mariod, A. A., Ibrahim, R. M., Ismail, M., \& Ismail, N. (2009). Antioxidant activity and phenolic content of phenolic rich fractions obtained from black cumin (Nigella sativa) seedcake. Food Chemistry, 116(1), 306-312.

Martín-Luengo, M., Yates, M., Domingo, M. M., Casal, B., Iglesias, M., Esteban, M., et al. (2008). Synthesis of p-cymene from limonene, a renewable feedstock. Applied Catalysis B: Environmental, 81(34), 218-224.

Martínez, V. A., Vasco, D. A., \& García-Herrera, C. M. (2018). Transient measurement of the thermal conductivity as a tool for the evaluation of the stability of nanofluids subjected to a pressure treatment. International Communications in Heat and Mass Transfer, 91, 234-238.

Mehdi, M., Asgar, A., \& Alderson, P. G. (2010). Effect of cinnamon oil on incidence of anthracnose disease and postharvest quality of bananas during storage. International Journal of Agriculture and Biology, 12(4), 516-520.

Menon, K. V., \& Garg, S. (2001). Inhibitory effect of clove oil on Listeria monocytogenes in meat and cheese. Food Microbiology, 18(6), 647-650.

Miladi, K., Ibraheem, D., Iqbal, M., Sfar, S., Fessi, H., \& Elaissari, A. (2014). Particles from preformed 23 
polymers as carriers for drug delivery. EXCLI journal, 13, 28. changes of microencapsulated Nigella sativa oil upon accelerated storage. International journal of food properties, 20(sup3), S2395-S2408. conditions of spray drying microencapsulation of Nigella sativa oil. Powder Technology, 315, 1-14. Munhuweyi, K., Caleb, O. J., Lennox, C. L., van Reenen, A. J., \& Opara, U. L. (2017). In vitro and in vivo antifungal activity of chitosan-essential oils against pomegranate fruit pathogens. Postharvest biology and technology, 129, 9-22. Nallamuthu, I., Parthasarathi, A., \& Khanum, F. (2013). Thymoquinone-loaded PLGA nanoparticles: antioxidant and anti-microbial properties. International Current Pharmaceutical Journal, 2(12), 202-207. Nazari, M., Ghanbarzadeh, B., Kafil, H. S., Zeinali, M., \& Hamishehkar, H. (2019). Garlic essential oil nanophytosomes as a natural food preservative: Its application in yogurt as food model. Colloid and Interface Science Communications, 30, 100176. MAPLE deposition of Nigella sativa functionalized Fe3O4 nanoparticles for antimicrobial coatings. Applied Surface Science, 455, 513-521. Nickavar, B., Mojab, F., Javidnia, K., \& Amoli, M. A. R. (2003). Chemical composition of the fixed and volatile oils of Nigella sativa L. from Iran. Zeitschrift für Naturforschung C, 58(9-10), 629-631. Nielsen, P. V., \& Rios, R. (2000). Inhibition of fungal growth on bread by volatile components from spices and herbs, and the possible application in active packaging, with special emphasis on mustard essential oil. International journal of food microbiology, 60(2-3), 219-229.

Olmedo, R. H., Nepote, V., \& Grosso, N. R. (2013). Preservation of sensory and chemical properties in flavoured cheese prepared with cream cheese base using oregano and rosemary essential oils. LWT-Food Science and Technology, 53(2), 409-417.

544 Paranagama, P., Abeysekera, K., Abeywickrama, K., \& Nugaliyadde, L. (2003). Fungicidal and antiaflatoxigenic effects of the essential oil of Cymbopogon citratus (DC.) Stapf.(lemongrass) against Aspergillus flavus Link. isolated from stored rice. Letters in Applied Microbiology, 37(1), 86-90. nanoemulsion formulation of Nigella sativa L. essential oil on human breast cancer cells. Ultrasonics Sonochemistry, 31, 449-455.

550 Ramadan, M. F. (2016). Chapter 30 - Black Cumin (Nigella sativa) Oils. In V. R. Preedy (Ed.), Essential 551 Oils in Food Preservation, Flavor and Safety (pp. 269-275). San Diego: Academic Press.

552 Ramadan, M. F., \& Mörsel, J. T. (2004). Oxidative stability of black cumin (Nigella sativa L.), coriander

553 (Coriandrum sativum L.) and niger (Guizotia abyssinica Cass.) crude seed oils upon stripping. European 554 Journal of Lipid Science and Technology, 106(1), 35-43.

555 Raybaudi-Massilia, R. M., Mosqueda-Melgar, J., \& Martin-Belloso, O. (2006). Antimicrobial activity of 556 essential oils on Salmonella enteritidis, Escherichia coli, and Listeria innocua in fruit juices. Journal of 557 Food Protection, 69(7), 1579-1586.

558 Sarwar, A., \& Latif, Z. (2015). GC-MS characterisation and antibacterial activity evaluation of Nigella 559 sativa oil against diverse strains of Salmonella. Natural product research, 29(5), 447-451.

560 Shaaban, H. A., Sadek, Z., Edris, A. E., \& Saad-Hussein, A. (2015). Analysis and antibacterial activity 561 of Nigella sativa essential oil formulated in microemulsion system. Journal of oleo science, 64(2), 223562232. 
Sharif, H. R., Abbas, S., Majeed, H., Safdar, W., Shamoon, M., Khan, M. A., et al. (2017). Formulation, characterization and antimicrobial properties of black cumin essential oil nanoemulsions stabilized by OSA starch. Journal of food science and technology, 54(10), 3358-3365.

Shi, C., Zhang, X., \& Guo, N. (2018). The antimicrobial activities and action-mechanism of tea tree oil against food-borne bacteria in fresh cucumber juice. Microbial pathogenesis, 125, 262-271.

Singh, G., Marimuthu, P., de Heluani, C. S., \& Catalan, C. (2005). Chemical constituents and antimicrobial and antioxidant potentials of essential oil and acetone extract of Nigella sativa seeds. Journal of the Science of Food and Agriculture, 85(13), 2297-2306.

Smith-Palmer, A., Stewart, J., \& Fyfe, L. (2001). The potential application of plant essential oils as natural food preservatives in soft cheese. Food microbiology, 18(4), 463-470.

Sultan, M. T., Butt, M. S., Anjum, F. M., Jamil, A., Akhtar, S., \& Nasir, M. (2009). Nutritional profile of indigenous cultivar of black cumin seeds and antioxidant potential of its fixed and essential oil. Pak $J$ Bot, 41(3), 1321-1330.

Sultan, M. T., Butt, M. S., Karim, R., Ahmad, A. N., Suleria, H. A. R., \& Saddique, M. S. (2014). Toxicological and safety evaluation of Nigella sativa lipid and volatile fractions in streptozotocin induced diabetes mellitus. Asian Pacific Journal of Tropical Disease, 4, S693-S697.

Tarhini, M., Greige-Gerges, H., \& Elaissari, A. (2017). Protein-based nanoparticles: From preparation to encapsulation of active molecules. International journal of pharmaceutics, 522(1-2), 172-197.

Terzi, V., Morcia, C., Faccioli, P., Vale, G., Tacconi, G., \& Malnati, M. (2007). In vitro antifungal activity of the tea tree (Melaleuca alternifolia) essential oil and its major components against plant pathogens. Letters in applied microbiology, 44(6), 613-618.

Tulukcu, E. (2011). A comparative study on fatty acid composition of black cumin obtained from different regions of Turkey, Iran and Syria. African Journal of Agricultural Research, 6(4), 892-895.

Venkatachallam, S. K. T., Pattekhan, H., Divakar, S., \& Kadimi, U. S. (2010). Chemical composition of Nigella sativa L. seed extracts obtained by supercritical carbon dioxide. Journal of food science and technology, 47(6), 598-605.

Vitoratos, A., Bilalis, D., Karkanis, A., \& Efthimiadou, A. (2013). Antifungal activity of plant essential oils against Botrytis cinerea, Penicillium italicum and Penicillium digitatum. Notulae Botanicae Horti Agrobotanici Cluj-Napoca, 41(1), 86-92.

Viuda-Martos, M., Mohamady, M. A., Fernández-López, J., Abd ElRazik, K. A., Omer, E. A., PérezAlvarez, J. A., et al. (2011). In vitro antioxidant and antibacterial activities of essentials oils obtained from Egyptian aromatic plants. Food Control, 22(11), 1715-1722.

Waithaka, P. N., Gathuru, E. M., Githaiga, B. M., \& Kimani, S. N. (2017). Control of Passion Fruit Fungal Diseases Using Essential Oils Extracted from Rosemary (Rosmarinus officinalis) and Eucalyptus (Eucalyptus agglomerata) in Egerton University Main Campus Njoro, Kenya. International journal of microbiology, 2017.

Walton, K., Walker, R., Van De Sandt, J., Castell, J., Knapp, A., Kozianowski, G., et al. (1999). The application of in vitro data in the derivation of the acceptable daily intake of food additives. Food and Chemical Toxicology, 37(12), 1175-1197.

Woo, C. C., Kumar, A. P., Sethi, G., \& Tan, K. H. B. (2012). Thymoquinone: potential cure for inflammatory disorders and cancer. Biochemical pharmacology, 83(4), 443-451.

Worthen, D. R., Ghosheh, O. A., \& Crooks, P. (1998). The in vitro anti-tumor activity of some crude and purified components of blackseed, Nigella sativa L. Anticancer research, 18(3A), 1527-1532.

Zaoui, A., Cherrah, Y., Mahassini, N., Alaoui, K., Amarouch, H., \& Hassar, M. (2002). Acute and chronic 
607 toxicity of Nigella sativa fixed oil. Phytomedicine, 9(1), 69-74.

608 